\title{
THE CONFLICT AGAINST CORRUPTION AND THE PURSUIT OF EFFICIENCY IN PUBLIC NEGOTIATION IN ITALY
}

\author{
Gianfrancesco Fidone ${ }^{*}$
}

\begin{abstract}
This work aims to investigate the relationship between the two diseases of public negotiation that is the inefficiency and corruption. For twenty years Italian Legislator trend, has been to fight corruption through the deprivation in the hands of public officials of the needed discretion to take efficient choices, through the tightening of purchasing procedures and contractual models. The path followed by the Legislator in fighting corruption can be criticized because it has a priori renounced to the efficiency, especially in the case of complex contracts, with the consequence of bad contract terms, overspending, poor quality, useless contracts, improper engineering, etc. By inverting the traditional approach, it is reasonable to argue that measures to combat and reduce the inefficiency can also have the indirect effect of reducing corruption. In fact, if corruption corresponds to a portion of the inefficiency and hides behind it, improving efficiency (i.e. the reduction of costs, the shortening of the times, quality improvement and ultimately the achievement of the performance) can reduce implementation space of corruptive pacts.
\end{abstract}

INTRODUCTION ............................................................................ 30

I. CORRUPTION AND INEFFICIENCY ...................................................... 32

II. TREND LiNES IN THE CONFLICT AGAINST CORRUPTION IN PUBLIC Negotiation: StIFFENING OF ENTRUSTING PROCEDURES AND SUBSEQUENT

LOSS OF EFFICIENCY ................................................................ 34

III. The RESEARCH OF INTEGRITY THROUGH THE PURSUIT OF EFFICIENCY... 38

A. Best Value and Integrity in the United Kingdom.......................440

CONCLUSIONS .............................................................................. 43

\section{INTRODUCTION}

This work aims to investigate the relationship between the two diseases of public negotiation in Italy that is the inefficiency and corruption. ${ }^{1}$

For this reason, it must be remembered that the concept of corruption is

\footnotetext{
* Professor of Administrative Law, University of Rome La Sapienza and LUISS Guido Carli. Research fields: Public Procurement, Project Financing, Public Private Partnerschip, Corruption and Efficiency of Public Admistration, Common Goods.

${ }^{1}$ The present work has been presented at the XII International Congress of SIDE-ISLE (Italian Society of Law and Economics) at the University of Turin, December 2016.
} 
multi-level and oscillates between legal, ethical and economic ${ }^{2}$. However, in the collective view the term corruption is often associated with specific types of offenses, subject of the penal law, to be challenged only on the repression plan. This strict meaning of the term is supported by a wider notion of corruption, which relates to various forms of political and administrative immorality, more properly attributable to administrative law, which can be prevented through the application of measures linked to this discipline. According to ANAC (National Anti-Corruption Authority) and the Department of Public Administration, the term "corruption" should be interpreted as including: (i) Of the entire range of crimes against the public administration regulated in Book II, Title II, Chapter I of the Criminal Code; (ii) of "situations where, regardless of the criminal law, it finds the administration's failure due to use for private purposes of the functions attributed" "Thus, such a formula also censures the private use of public office, though not having criminal relevance. In this sense, it may be useful to recall that perspective proposed by the social sciences which looks at corruption as " the abuse of entrusted power for private gain" ("l'abuso del potere affidato al fine di ottenere un guadagno personale" ${ }^{4}$. Upon such definition, four elements would characterize corruption, i.e., the entrusted power, the person in charge with it, the abuse linked to a distorted exercise of power, the private advantage achieved ${ }^{5}$.

\footnotetext{
${ }^{2}$ Among the most recent studies about corruption, can be mentioned: Vannucci A., Atlante della corruzione, Torino, Edizioni Gruppo Abele, 2012; Palazzo F. (edited by) Corruzione pubblica. Repressione penale e prevenzione amministrativa, Firenze, Firenze University Press, 2011; Mattarella B. G., Le regole dell'onestà. Etica, politica, amministrazione. Il Mulino, 2007; Merloni F.-Vandelli (edited by) La corruzione amministrativa, Passigli, Firenze 2010. In the past there have been some commissions that have studied the issue of corruption and its administrative remedies. We can remember: the one appointed by the President of the Chamber presided by Sabino Cassese in 1996 (whose report is published in La lotta alla corruzione, Roma-Bari, Laterza, 1998); the one appointed by the Minister of Public Service and presided by Gustavo Minervini that same year; the one appointed by the Minister of Public Service and presided by Roberto Garofoli in 2011 (whose report is published in La prevenzione della corruzione. Per una politica di prevenzione, in http://www.governo.it/GovernoInforma/documenti/20121022/rapporto_corruzione-DEF.pdf). ${ }^{3}$ Piano Nazionale Anticorruzione, 2013, at 13, available on the corporate webside of ANAC, www.anticorruzione.it.

${ }^{4}$ Pope J., Confronting Corruption: The Elements of a National Integrity System, Trasparency International Source Book, 2000.

${ }^{5}$ According to economic theory, corruption is the result of an agency relationship existing between administrators-agent (for example, politicians, mayor, etc.) and administrated-principle (beneficiaries of the administration, which, for example, will benefit the public work or the service). In fact, administrators and politicians are subjects who should realize the interest of the administered community and on this they are selected directly (in the case of politicians with elections) or indirectly (if public administrators are assumed by other public officials who should always treat the public interest of administered society and, in this case, there would be an additional issue of agency). In this agency relationship we have an asymmetry of information against the principle-
} 
The reasons for the concentration of corruption phenomena in the public contracts sector seem different ${ }^{6}$ : It is a sector characterized by the use of large sums of public money, which attract illegal interests; there is a high pulverization of demand held by a variety of public authorities and public law organizations, more easily removed from inspections and rules provided by national legislation (also, as we have seen, for a derogation of the law to the general rules); the complexity of the discipline and the unstable legal framework which characterize the sector, encourage the occurrence of pathological phenomena. The underlying assumption is that the more mediocre and not transparent the action of contracting authorities and less submitted to adequate controls (made more difficult by the controller lack of information, by the complexity of the contracts and the inefficiency of the controller's powers), the more concrete is the risk of corruption.

\section{CORRUPTION AND INEFFICIENCY}

Corruption and inefficiency are two distinct diseases of the administrative activity, since it can occur even without corruption (i.e., in the case of incorruptible officials). Otherwise, it is more difficult to argue that there may be corruption which does not generate inefficiency.

Corruption coincides to the abuse of the public official power in exchange for illicitly paid consideration. Inefficiency results into poor management of public resources, due to the bad quality of purchased goods and services, to the

administered community, which concerns the work of administrators-agent. Consequently, is not said that public administrators protect the interests of individuals (for example, in procedures addressed to the adjudication of a contract, in its execution or in renegotiations). It could happen, in fact, that, taking advantage of the informative disadvantage of the administered community, the administrator (who should represent it and take care of its interests) encourages its personal advantage to the detriment of the public interest. In this context, therefore, corruption phenomena may be inserted, since, in the absence of adequate controls and information of citizens represented, the official might find it convenient to be bribed and realize his own interest (which coincides with that of the private) and not with that of the administered community. On this point, see Napolitano G., Analisi Economica del diritto pubblico, Il Mulino, 2009, at 203 and ss.; Napolitano G., La logica del diritto amministrativo, Il Mulino, 2014, at 28 and ss.

${ }^{6}$ The issue of corruption in public contracts has been, among others, treated by: Sandulli M. A. and Cancrini A., I contratti pubblici, in Merloni F., Vandelli L. (edited by), La corruzione amministrativa. Cause, prevenzione e rimedi, Passigli Editori, 2010, at 437 ss.; Vannucci A., Il lato oscuro della discrezionalità. Appalti, rendite e corruzione, in Comporti G. D., (edited by), Le gare pubbliche: il futuro di un modello, Editoriale Scientifica, 2011; Racca G. M., La prevenzione e il contrasto della corruzione nei contratti pubblici (art. 1, subparagraphs 14-25, 32 and 52-58), in Mattarella B. G. (edited by), La legge anticorruzione. Prevenzione e repressione della corruzione, Giappichelli, 2013; Clarich M., The Rules on Public Contracts in Italy after the Code of Public Contracts, ITALIAN JouRnal OF Public LaW 43-56 (2013). It is also allowed to return to Fidone G., La corruzione e la discrezionalità amministrativa: il caso dei contratti pubblici, in Il Giornale di Diritto Amministrativo n. $3 / 2015$, at $325-344$. 
extended timetable of public procurement, to the increased expenditure. If the public interest underlying the public contract still remains to provide such quality works and services, in contractual term and without wasting public money, inefficiency exactly lies into opposite pole compared to the realization of that public interest.

There may be inefficiency without corruption even in presence of very honest officials (both during adjudication and the execution of the contract). Such an inefficiency can be caused by poor adjusting (including the so-called over-regulation), by misrule (due to bad organization, to public officials inability, etc.), or to both things together.

Poor adjusting examples are, for instance, the compression of the contracting authorities administrative discretion and the hardening of entrusting procedures and contractual models, through automatism; the provision of formalism for the admission and participation of enterprises to the procedures, leading to exclusion of good offers and the adjudication with worse deals than the excluded ones; the increase of companies performances on the occasion of the competition with useless and exhausting detailed rules. Unfortunately, the list of examples could continue. In such cases, the contracting authorities, which must apply rules generating inefficiency cannot, therefore, achieve inefficient choices.

The other case is that of mismanagement, in which the physiological informational disadvantage of contracting authorities seems central (both during adjudication and the execution of the contract) in relation of economic operators (information asymmetry). Such an informational disadvantage may determine, at the adjudication stage, cases of so-called adverse selection (the choice of the worst offer or not the better one) ${ }^{7}$, i.e. the implementation stage of the contract, cases of so-called moral hazard (i.e. bad quality of execution). To avoid such phenomena, which increases the more complex the object of the contract is, it is necessary to improve the degree of contracting authorities information through their specialization, their unification with a consequent reduction of the number, etc. The two cases of bad regulation and mismanagement, obviously, add up together (multiplying the effects) when Legislator provides the administrations of unsuitable instruments to improve their informative background and dictate them to apply institutions inefficient in itself. So it happened with the dispositions of the Code of public contracts (by claiming to contain corruption) entrusted the administration with unsuitable instruments procedures to increase their information on the

\footnotetext{
${ }^{7}$ Economists define effect of adverse selection the effect because of which they have more possibilities to participate in voluntary exchange those subjects (buyers or sellers) that less have favorite quality. For example: Frank R. H., Microeconomia, Milano, 2004 (italian version).
} 
contracts to be awarded before the final call of tenders (for instance, hindering the application of the competitive dialogue).

\section{TREND LiNES IN THE CONFLICT AGAINST CORRUPTION IN PUBLIC NEGOTIATION: STIFFENING OF ENTRUSTING PROCEDURES AND SUBSEQUENT LOSS OF EFFICIENCY}

For twenty years Legislator trend, from the known facts of Tangentopoli, has been to fight corruption through the deprivation in the hands of public officials of the needed discretion to take efficient choices, through the tightening of purchasing procedures and contractual models. The Legislator has therefore replaced the Administration, predetermining competitive tendering and strict contractual models (which continue to multiply) that the latter has only to apply with no chance of making the right choices for the concrete case. The administrative discretion has been, therefore, considered opportunity for corruption.

After the known facts of Tangentopoli, $1992^{8}$, the regulation of public works was deeply innovated with the Law 11 February 1994, n. 109 socalled "Merloni". Such discipline, inspired by the general distrust for the tendering entities and enterprises, has been animated by a purifier spirit and aimed at dealing with corruption. It was based, however, on two questionable assumptions.

In the first place there was the belief that the corruptive phenomena would mostly concern awarding of contracts, with underestimation of the execution phase of the contract and the previous assignment. The execution phase of the contract, on the contrary, is undoubtedly the most critical phase, in which the AVCP found the largest number of alerts ${ }^{9}$. The European Commission also noted that "according to empirical studies, corruption in Italy is particularly lucrative in the next phase of the awarding, especially during the quality or completion controls of pears contracts/supplies/services" $" 10$.

\footnotetext{
${ }^{8}$ We refer to the known Italian corruption scandals of the early nineties, emerged thanks to "Mani Pulite" investigation, conducted by the magistrates of Milan, which determined, in fact, the crisis of traditional political parties and the end of the so-called "Prima Repubblica".

${ }^{9}$ Annual report 2013 Authority for the Supervision of Public Contracts (AVCP).

${ }^{10}$ European Commission report about corruption, 3.02.2014, COM 2014/38, annex 12 about Italy. (Compare also "Public Procurement in Europe: Cost and Effectiveness", 2011, on www.ec.europa.eu). It may also be mentioned, as an example, a data provided by the newspaper La Repubblica (Source: www.larepubblica.it last visit December 22, 2011) according to which the surveys carried out by more prosecutors in the period 2007-2010 on 33 large projects awarded revealed as the cost incurred by national treasuries is risen from an initial 574 million euro to 834 million final, with an increase, therefore, equal to $45 \%$ of initial award value.
} 
Secondly, there was the belief that the administrative discretion was an opportunity for corruption, and that, on the contrary, the awarding automatic mechanisms, as a result of procurement procedures and rigid casts, could reduce it.

On the basis of these two assumptions stated above, it followed a law that has governed (with some exceptions) the only awarding phase of the contracts with the hardening of procedures and the declared intention to reset the administrative discretion.

Such a purifier spirit nature did not change with the Legislative Decree no. 12 April 2006, n. 163 "Code of public contracts for works, services and supplies", with which the Legislator brought together in a single regulatory text all the matter of public contracts, implementing the transposition of Directives 2004/17/EC and 2004/18/EC. It is known, in fact, the resistance to the implementation of the new Code of flexible institutions (for instance, the competitive dialogue) governed by the 2004 Directives. Moreover, the writing of the Code, represented the starting point for an endless series of correctives and amendments which gave great uncertainty to the sector.

Economic theory, however, shows that contracting procedures and strict and full of heaviness contractual mechanisms, which also have been a source of uncertain legislation and have revealed unsuited for the realization of many works so much to often lead to the use of exceptional procedures, create inefficiency.

This is not the appropriate location in which investigate this reasoning but, as an example, we can refer to the "market for lemons" of Nobel Prize George Ackerlof ${ }^{11}$. Even from the "equivalence theorem" of the Nobel laureate William Spencer Vickrey ${ }^{12}$, fundamental in auction theory, it can be

\footnotetext{
${ }^{11}$ Ackerlof G., The Market for Lemons: Quality Uncertainty and the Market Mechanism, QUARTERLY JOURNAL OF ECONOMICS (1970). Suppose a market with high information asymmetry at the expense of the buyer than the seller, which is that of used cars, in which only the sellers exactly know the car quality in their possession while buyers do not have adequate tools to compare it. In this market, if the buyer would set as a criterion of choice only the price (even calling markdowns on that price), it would only compare sellers who own a car matching that very quality or lower than the price set by the seller. Would not assume the exchange sellers who possess high quality cars than that corresponding to the price indicated by the buyer. Since the buyer is not able to recognize the car quality offered, he would accept the exchange with the seller ready to give his car at the lowest price, but it is also the one who possesses a poorer quality car, corresponding to that price (since anyone who is aware that his car is worth more than the exchange price would not be willing to sell it for that price). It would have, therefore, a competitive mechanism that would end up to select the benefit of worse quality, using a classical example of adverse selection. George Akerlof, Michael Spence and Joseph Stiglitz received in 2001 Nobel for Economy for their researches on asymmetric information.

${ }^{12} \mathrm{Cfr}$ W. S. Vickrey, Counterspeculation, Auctions, and Competitive Sealed Tenders, 16 (1) JouRnAL OF FinANCE 8-37 (Mar., 1961). Vickrey won Nobel for Economy in 1996.
} 
deduced, without going into detail, that (in the absence of hypothetical conditions that justify the equivalence, not found in nature) the type of award procedure must be carefully chosen in relation to the object of contract.

Thus, the most suitable choice of the awarding procedure for a public contract should depend on the specific case, i.e. by the characteristics of the market and by those of the good to be awarded and not being predetermined in the abstract ex ante. By restricting the reasoning to tendering models which are covered by positive law, the choice to be made concerns on the one hand the selection criterion and on the other the tender procedure. For example, if for contracts which have as their object standardized goods may be true that the best criterion of the selection is the one of minimum price, for less straightforward contracts that have as their object goods with peculiar characteristics, it will be considered preferable the (more flexible) criterion of economically most advantageous tender ${ }^{13}$.

The finishing point of the reasoning is that for complex contracts, where the informational disadvantage of the public administration about quality and characteristics of the procured goods is particularly large, it is necessary the use of flexible procedures (alternative to those restricted or opened), such as the competitive dialogue or competitive negotiations to allow the administration to learn (and improve its initial information) during the proceedings. In this way, the final choice may be made on the basis of a greater experience of information than the one possessed at the beginning of the procedure and so it will reduce the risk of adverse selection ${ }^{14}$.

The restriction of administrative discretion, especially in the case of complex contracts, is a source of inefficiency, since it prevents the construction of

\footnotetext{
${ }^{13}$ In this different perspective, among the numerous writings, AA.VV., HANDBOOK OF ProcUREMENT, (N. Dimitri, G. Piga, G. Spagnolo eds., Cambridge University Press, 2006); AA.VV. The Economic THEORY OF AuCTIONS, vol. I and II, (P. Klemperer eds., Cheltenham, UK, Edward Elgar, 1999); P. Klemperer, What Really Matters in Auction Design (Nuffield College, Oxford, Feb., 2001), http://www.nuff.ox.ac.uk/users/klemperer; R. P. Mcafee \& E. J. Mcmillan, Auctions and Bidding, 25(2) Journal of Economic Literature 699 ss. (1987); P. Milgrom, Auctions and Bidding: A Primer, 3(3) Journal of Economic Perspectives 3 ss. (1989); P. Milgrom, Putting Auction THEORY TO WORK (Cambridge University Press, 2004); L Prosperetti and M. Merini, I contratti pubblici di lavori, servizi e forniture. Una prospettiva economica, in AA.VV., Commentario al codice dei contratti pubblici edited by M. Clarich, Giappichelli, at 27 ss. (2010); K. M. Schmidt \& E. M. Schnitzer, Methods of Privatization: Auctions, Bargaining and Give-Aways, in PRIVATIZATION AT THE END OF THE CENTURY 97 ss (H. Giersch ed., Berlino, 1997); E. Wolfstetter, Auctions: An Introduction, 10(4) JOURNAL OF ECONOMIC SURVEYS 367 ss (1995).

${ }^{14}$ On this point, allow to return to Fidone G., Le concessioni come contratti complessi: tra esigenze di flessibilità e moltiplicazione dei modelli, in Cafagno M., Botto A., Fidone G., Bottino G.,

Negoziazioni Pubbliche - Scritti su concessioni e partenariati pubblico-privati (Giuffrè, 2013); Fidone G, Le concessioni di lavori e di servizi alla vigilia del recepimento della direttiva 2014/23/UE, in Rivista italiana del diritto pubblico comunitario 101—193 (1/2015).
} 
procurement procedures (as well as contractual models) accurately calibrated on the contract to be procured and followed. The lack of competitive negotiations prevents the public authorities to improve its knowledge of the complex contractual object and to make more informed choices.

The path followed by the Legislator in fighting corruption (i.e. the one of deprivation of administrative discretion) can be criticized because it has a priori renounced to the efficiency of the procedures in pursuing it. In other words, in our country to fight corruption we have renounced $a$ priori to the efficiency, especially in the case of complex contracts, with the consequence of bad contract terms, overspending, poor quality, useless contracts, improper engineering, etc.

Experience demonstrates, moreover, that the rigidities of the regulation of public contracts do not even oppose in any way the spread of corruption, which remains a serious disease of the Italian public contracts. In recent years in Italy, in fact, important facts of corruption linked to the construction of public works have still emerged. The connection are, for example, with the works of Expo Milano 2015, with those intended to complete the Mose in Venice $^{15}$, with the facts of "Mafia capital" in Rome, with the recovery from the earthquake in L'Aquila in 2009. These phenomena lead us to think to the general problem of corruption in public procurement and about Legislator actions to oppose it.

It can also be observed that the rigidity of the award procedures prescribed in the general regulations determined their uselessness for many large and complex projects and forced internal Legislator to consider specific derogations disciplines. Such derogations to the general rules have not been transformed into competitive negotiations (aimed at improving the knowledge of the public authorities through competitive comparison with economic operators, such as a competitive dialogue) but in direct contracts without competition, resulting in further loss of efficiency ${ }^{16}$.

In order to remedy at this situation, in 2012 a reform has been launched (which contains a number of specific provisions relating to the procurement sector), which has for the first time introduced a comprehensive set of rules

\footnotetext{
${ }^{15}$ On the events of the Mose in Venice, please see Clarich M. \& Fidone G., The Execution of Large Complex Works Amid Problems of Efficiency and Risks of Corruption: The Case of the Mose Project In Venice in Resilience of Art Cities to Flooding. SuCCess and Failure of the Italian EXPERIENCE 311-328 (Bardi Edizioni, Rome, 2016).

${ }^{16}$ For example, in the case of Mose in Venice the dealer Consorzio Venezia Nuova was selected as an exception to the general rules on public works on the basis of the. 11/29/1984 n. 798 embodying "new interventions to protect Venice" (so-called second special law for Venice). That derogation justified the general concession and all subsequent acts. Thirty years later, the work is not yet completed and their results are scheduled for 2016. They are known scandals linked to episodes of widespread corruption that have emerged in the course of 2014.
} 
aimed at preventing corruption. In this context, the National Anti-Corruption Authority (ANAC) has assumed a central role. The reference is to the L. 06/11/2012, n. 190 and D.L. June 24, 2014, n. 90, converted from L. $08 / 11 / 2014$, n. 114 . The new measures have formed an undoubted change in trend compared to the previous structure of anti-corruption legislation to the field of public contracts.

The Italian legislator seems to have recognized that inefficiency and corruption are two different evils that should be fought with suitable different remedies. Corruption must be fought without sacrificing a priori to the efficiency of contracts, through measures that do not limit the administrative discretion in procurement procedures, restricting the rules of the tender. The tender for the selection of contractors must have as aim the efficiency of procedures and cannot be considered "a magic wand" to solve all the problems of inefficiency and corruption. Outside the competition rules, it is necessary to focus on measures against corruption, both preventive and suppressive, that have as their assumption the transparency of the administrations.

\section{THE RESEARCH OF INTEGRITY THROUGH THE PURSUIT OF EFFICIENCY}

On such considerations, it seems appropriate an additional step forward, which is founded on the inversion of the relationship between efficiency and corruption (i.e., diametrically opposed to the traditional Italian, based on the prevention of corruption without an evaluation of the cost in terms of efficiency).

The argument may start by considering that one of the characteristics that distinguish the two different diseases of the administration in question is the one of their observation. Corruption is a hidden phenomenon and it is difficult to be measured.

To have an idea of the consistency of the phenomenon, specifying that they are data supported on the perception of those surveyed and not real data, it can be referred to a special Eurobarometer survey of 2013. This survey shows the great perception of corruption in procurement, both in the case of central authorities well as local one ${ }^{17}$. In fact, $70 \%$ of Italian interviewed says that corruption is widespread in government procurement managed by national authorities, compared to $56 \%$ of the EU average (only $9 \%$ say that

\footnotetext{
${ }^{17}$ It is a survey of the European Commission, based on the perception of corruption by the respondents in different Member States. These data, therefore, have not to be considered fully reliable, especially if considered individually. However, they can give an indicative idea of the measured phenomenon, especially through the comparison between individual countries.
} 
it is rare and $0 \%$ that it does not exist). $69 \%$ of Italian interviewed thinks corruption is widespread in contracts managed by regional or local authorities, compared with $60 \%$ of the EU average (only $11 \%$ think it is rare and $2 \%$ that is non-existent).

On the contrary, the inefficiency can be identified in the available data, in the performance indicators, in the comparison between the costs incurred and the time taken by the various authorities related to similar activities.

For example, the high speed in Italy cost 47.3 million Euro per kilometer for the section Rome-Milan, 74 million per kilometer for the section Turin-Novara, 79.5 million per kilometer for the section NovaraMilan and 96.4 million per kilometer for the Bologna-Florence stretch. These data are alarming, considering that similar works cost just 10 million kilometers of the Paris-Lyon, 9.8 million per kilometer for the section Madrid-Seville and 9.3 million for the section of the Tokyo-Osaka ${ }^{18}$. Clearly these differences can depend on many different factors of inefficiency and not necessarily on corruption phenomena, but the data are certainly alarming.

So, the inefficiency can be less easily hidden by corruption, since it can be found in the data showing that in Italy works cost more than in other countries, have longer times and often remain unfinished. It is believed that behind these data may hide corruption phenomena but, nevertheless, there can be no certainty of it until criminal investigations do not demonstrate it. In any case, the inefficiency data also include the consequent inefficiencies due to possible corruption, since it is reasonable to think that corruption generates inefficiency.

The fact that corruption is a hidden phenomenon, however, also makes it difficult to verify the effectiveness of the instruments aimed at its prevention. On the contrary, since the inefficiency encountered by real data, the effectiveness of the instruments aimed to pursuit of efficiency is more easily assessed.

So, the inefficiency can be less easily hidden by corruption, since it can be found in the data showing that in Italy works cost more than in other countries, have longer times and often remain unfinished. It is believed that behind these data may hide corruption phenomena ${ }^{19}$ but, nevertheless, there

\footnotetext{
${ }^{18}$ The source of such information is: Cicconi I., Il libro nero della TAV, 10.09.2011, www.ilfattoquotidiano.it. The same information are also mentioned by the document of the European Commission COM (2014) 38 final Bruxelles, 3.2.2014-ANNEX 12-Allegato sull'Italia della Relazione della Commissione al Consiglio e al Parlamento Europeo-Relazione dell'Unione sulla lotta alla corruzione.

${ }^{19}$ For example, Cantone R. \& Di Feo G., Il male italiano-liberarsi dalla corruzione per cambiare il Paese, Rizzoli, 2016.
} 
can be no certainty of it until criminal investigations do not demonstrate it. In any case, the inefficiency data also include the consequent inefficiencies due to possible corruption, since it is reasonable to think that corruption generates inefficiency.

By inverting the traditional approach which has already been described, therefore, it is reasonable to argue that measures to combat and reduce the inefficiency can also have the indirect effect of reducing corruption. In fact, if corruption corresponds to a portion of the inefficiency and hides behind it, improving efficiency (i.e. the reduction of costs, the shortening of the times, quality improvement and ultimately the achievement of the performance) can reduce implementation space of corruptive pacts.

If the full efficiency arrangements achieved, it will reduce to zero the space for corruption or, more correctly, a space just might persist for neutral forms of corruption to the efficiency which, however, would not be an obstacle to the achievement of the public interest related to the realization of good works with a limited expense. Such forms of corruption would remain, of course, undesirable from an ethical and public morality point.

The legislation on public procurement, therefore, should pursue the objective of efficiency and the realization of this aim could remove inefficiency spaces within which corruption is hidden and can be realized. In this sense, the implementation of the new sectoral directives should therefore proceed without further delay. Being said that, we do not want certainly argue that specific measures to prevent corruption are not equally useful, but they must not have the effect of determining efficiency losses, creating more edge behind which corruption can hide.

\section{A. Best Value and Integrity in the United Kingdom}

A proof of the supported theory may be the simple observation that countries that have better data on public procurement efficiency (and more generally of administrative activity) are also those in which it is less felt the problem of corruption and where the citizens perceive it less. It may be useful briefly to recall the case of the United Kingdom.

The United Kingdom transposed the Directive 2014/24/EU public procurement in ordinary areas through the Public Contracts Regulations 2015 , which is (by tradition) almost verbatim reproduction, with a few additions. Thus, such as Directive 2014/24/EU gives a limited space to the fight against corruption (taking care of the only efficiency of procurement procedures), also the Public Contracts Regulations 2015 gives little attention to this subject, reproducing the art. 24 and 25 of the corresponding Articles 
24 and 57 of Directive 2014/24/EU on conflict of interest ${ }^{20}$.

The fundamental concept around which turns the whole public contract law in the UK is the so-called Best Value, which refers to the "best possible use of public money" or "best value for money" (so-called "Best Value Procurement"). The Best Value appears, therefore, attributable to the concept of efficiency, which in any case is its assumption ${ }^{21}$.

This concept, however, does not have a unique definition.

By reference to public services of local governments, for example, the Best Value has been identified in four constitutive elements $\left.{ }^{22}: 1\right)$ The obligation of the authorities to guarantee the continuity of public services and their efficient provision according to the canons of economy; 2) respect for the principle of competition, not as an end in itself but as an instrument for improving the quality of services (also through instruments for consultation of local communities); 3) the introduction of an accurate and effective system of control and the performance measurement, in order to be able to monitor the performance of the services $^{23}$; 4) the provision of rewards or penalties for local authorities, in the case of failure to achieve the planned performance ${ }^{24}$. In the document itself is stated that: "In sum, best value can be thought of as a process through which economic, efficient, and effective services are to be obtained in order to properly respond to local stakeholders. This implies that accountability is enhanced".

\footnotetext{
${ }^{20}$ The provisions relating to corruption are Articles. 24 e 57 of the Public Contracts Regulations 2015, which in fact go to incorporate Articles. 24 e 57 of the Directive 24/2014/EU, faithfully reproducing the content.

${ }^{21}$ The idea of Best Value appears in 1997 in a document of the Department of Environment, "Twelve Principles of Best Value", which anticipated the fundamental principal around which the Labour government would turn the new regulation of public service that it was preparing to define to replace the "Compulsory Competitive Tender" of the previous Conservative government, whose results were considered unsuccessful by the new political majority. It is also proposed again in the Local Government Act 1999. Neither in that legislation moment the concept of "Best Value" is properly defined, rather referring to "Best Value Authorities", i.e. those local authorities arraigned to apply the "Best Value" policy ("A Best Value authority must make arrangements to secure continuous improvement in the way in which its functions are exercised, having regard to a combination of economy, efficiency and effectiveness" (LGA 1999, Section 3(1)).

${ }^{22}$ Modernising Local Government: Improving Local Services through Best Value, by Department of the Environment, Transport and the Regions, 1998.

${ }^{23}$ Performance in delivering services should have been monitored by the so-called. Best Value Performance Reviews (BVPRs), on the basis of adhesion to the Best Value Performance Indicators, partly centrally identified by Law and partly referred to the autonomy of individual local authorities. They relate to the strategic goals, the results of their pursuit, the quality of provided services, and the degree of accessibility of the various services for the most vulnerable social groups.

${ }^{24}$ In case of positive result the local government involved would receive reward incentives, while in the case of a negative result a direct intervention of the central government was expected, with binding rules or, in the worst cases, taking back the responsibility to itself of dispensing function service.
} 
We must highlight the fact that this concept has emerged as a critical response to the pursuit of the end of competition to itself (Compulsory Competitive Tendering) which could lead to the loss of quality and efficiency objectives in the field of public services.

It is interesting to note that the fight against corruption is not a direct aim of the Best Value policy but it looks necessarily constituting a natural consequence of it, since it requires the creation of an (efficient) environment, which is shortly permeable to corruption phenomena. In fact, where the contracts were adjudged to the outcome of corruption phenomena, the Best Value would be affected by the cost of corruption that would prevent the best expenditure of public money. Therefore, where the Best Value policy is properly and effectively implemented, would leave no room for corruption.

It does not mean that the UK neglects the specific regulation for combating Corruption. The Bribery Act 2010 is a penal law and as such it is primarily responsible of the repressive aspect ${ }^{25}$. However, it contains three specific sections (the 7, the 8 and 9) relating to the prevention of corruption phenomena ${ }^{26}$. Into United Kingdom Law can be found corruption prevention measures that may have bound nature and can be entrusted to the exercise of discretion by the contracting Authority.

\footnotetext{
${ }^{25}$ Before 2010, rules against corruption were present in three very statutes dating back over time:

"Public Bodies Corrupt Practises Act 1889", "Prevention of Corruption Act 1906" and "Prevention of Corruption Act 1916". As a whole, these three statutes went to hit the corruption phenomena in both the public and the private sector. In 2010 these three statutes have been repealed and replaced by the "Bribery Act", which has intensified the United Kingdom's commitment to the fight against corruption both within and outside its borders. The "Bribery Act" criminalizes corruption both from active side and the passive one, as the activity that induce a person to accomplish a certain activity or to refrain from doing it in exercising public functions, relating to a particular business or when carrying a professional activity ("The giving or receiving of a bribe as an inducement for a person to do or refrain from doing anything in the exercise of his public functions, in connection with a business or in the course of his employment"). The Bribery Act also contains provisions aimed at countering the manifestation of international corruption phenomena, with special regard to developing countries, including those aimed at curbing corrupt practices implemented by British companies in order to obtain the award of contracts in these Countries. Besides being forbidden and punished at the level of statutes, corruption in the UK is also forbidden by common law. The crime of corruption of common law takes on partially different characters, as it only refers to corruption in the public sector and is defined as "the receiving or offering any undue reward by or to any person whatsoever, in a public office, in order to influence his behavior in office, and incline him to act contrary to the known rules of honesty and integrity".

${ }^{26}$ For example, Section 7 firmly proclaims that a "commercial organization" has the opportunity to avoid any responsibility under criminal law for the consummation of acts of corruption, where it proves that it has implemented all the necessary procedures to prevent such acts. Basically, it is expected as exonerating evidence that of the fact that the prevention of corruption has been properly and actually pursued by "commercial organization". Section 9 entrusts on the Secretary of State responsible on the field the specific obligation of turning to the above-mentioned "commercial organizations" guidelines aimed at a proper prevention of corruption. These are the only measures that the Bribery Act 2010 dedicated to the prevention of corruption.
} 
For example, without any pretension to completeness, institutions related to the so-called disqualification ${ }^{27}$, are contemplated and widely used, which can be translated into "debarment", "exclusion", "suspension", "rejection", "blacklisting". It deals with the preventive measures that tend to prevent subjects who are responsible for illegitimate behaviors to participate in the future public contracts ${ }^{28}$. The pacts of integrity are also used, containing formal commitments of the supplier not to put in place corruptive activities (including, in some cases, the appearance of collusion with other competitors), with related penalties, in case of default.

With regard to public officers, there are measures to protect the administration from conflict of interest, that are resolved even in procedures that ensure staff rotation (in order to prevent the establishment of a risk of corruption relations). Moreover, public officials who are in conflict of interest situations must declare it and not participate in the procedure for awarding contracts that generate the conflict itself. Moreover, they are planned approvals at various levels of the decisions leading to the procurement of a public contract within the contracting entities.

Such measures, however, are part of a British general order tendency not to pursue corruption by using specific regulatory instruments. The search for the Best Value, in fact, is (indirectly) considered useful to the prevention of corruption, evidently considered a value that is included in the more general efficiency.

\section{CONCLUSIONS}

The example of the UK confirms the theory that in the first place it is necessary to pursue efficiency of public procurement, through a regulation

\footnotetext{
27 "Disqualifications" can be applied after a wide range of behaviors and crimes, not necessarily related to public procurement, such as tax fraud, corruption, money laundering and criminal association. Moreover, the British doctrine has set the problem if disqualification might violate the principle of "double jeopardy", i.e. the ne bis in idem, since, on closer inspection, constitutes a second penalty for an act for which It has already been sanctioned previously. According to a particular legal precedence, which was inaugurated in 2005 by the judgment EWCA, Borders (UK) vs. Commissioner of Police of the Metropolis, where the multiple resulting penalties to the same did not have the same purposes, there would be no violation of the rule prohibiting the "double jeopardy".

${ }^{28}$ Disqualification can be bound or discretionary. In the former case, the law requires that all the providers who are guilty of a particular crime must be necessarily excluded from the possibility of contracting with the public administration for a given period of time. In the latter case, even though the law abstractly provides mandatory exclusion from certain contracts for specific crimes, the individual contracting authorities may decide in a specific case to invoke the concept of "public interest" and thus adjudge a specific contract to a given operator, despite its sentence. At other times, disqualification appears as a discretionary measure, because the individual contracting authorities are given the opportunity to use its discretion whether to exclude or not (in relations to mention corrupt events that involve it) the supplier in question by individual contract.
} 
of the sector aimed at this aim. With this we do not want to claim that even specific measures aimed to prevention of corruption are not useful, but they must not have the effect of determining efficiency losses, creating more edges behind which corruption can hide.

In light of the above, therefore, we can conclude that corruption and inefficiency are two distinct and separate diseases that afflict public sector contracts. The fact remains, however, that between the two diseases there is a connection and, in particular, that the pursuit of efficiency of public procurement may constitute the most effective way for contrast the corruption that is behind these inefficiencies. This seems the most suitable system to create the antibodies within the administration to avoid that corruption can be generated.

The efficiency of public procurement, in turn, passes through the recognition of the required amount of discretion on the part of the contracting authorities, as suggested by the latest European directives of $2014^{29}$. Based on these directives, in Italy the new public contracts code, which replaces that of 2006, was adopted by Legislative Decree. 18/04/2016 n. 50. This may not be the center to go into detail, but this Code has undoubtedly established the definitive change of course compared to past trends and, on the basis of flexible procedures, it aims to reach an efficient system of public contracts. Only the discretion and flexibility, in fact, can ensure proper management of the complexity of public contracts and, simultaneously, ensure a steady improvement in contracting, even under the learning profile of a greater number of information.

A transitional period will obviously be needed in which the public administrations may learn to use the new instruments. It will be necessary to assure that the procedures of trust of the public contracts are not bridled in the affirmation of competition end in itself (Compulsory Competitive Tendering), but actually pursue the objective of selecting the best tender (Best Value); even the transparency of procedures should not end in itself (with the effect of creating unnecessary bureaucratic burden), but it must be part of a reordering of the monitoring instruments (for which only the most essential information on tenders and not the useless ones are needed ) and be aimed at making them more effective.

However, the reform does not appear complete yet. In fact, the recognition of a greater discretion, which requires confidence in the public administration, requires an adequate system for measuring achieved results

\footnotetext{
${ }^{29}$ Reference is made to Directive 2014/23/EU on works and services concessions; to 2014/24/EU regarding work, services and supplies contract in the ordinary sectors; to 2014/25/EU on contracts in the utilities sectors.
} 
and their control.

Also judicial control will necessarily have to move on the result of the general administrative activity, for instance the results of a procedure of trust or the execution of a contract, in terms of expense, quality, timeliness. For these purposes, it is necessary to determine a priori what the result (performance) must be planned by public administration, even through the use of universally recognized standard values, and later proceed to the verification of the result achieved.

All of this should determine greater and effective accountability of contracting authorities and individual directors and officers who work within them (through an adequate system of rewards and penalties), called to ensure the efficiency and the fight against corruption in the public sector contracts. 